\section{Added Value and Pricing With Information Technology}

\author{
By: Barrie R. Nault
}

Graduate School of Management

University of California, Irvine

Irvine, CA 92717

U.S.A.

brnault@uci.edu

\author{
Albert S. Dexter \\ Faculty of Commerce and Business \\ Administration \\ University of British Columbia \\ Vancouver, B. C. V6T IZ2 \\ CANADA \\ aldexter@unixg.ubc.ca
}

good without IT. Compared to the price without $I T$, statistical analysis of the supplier's pricing history demonstrates that the application of IT to commercial fuel yielded price premiums of between five and 12 percent of the retail fuel price.

Keywords: Economic impacts, interorganizational systems, pricing

ISRL Categories: BA01, $\mathrm{HAO}, \mathrm{AF} 1302$

\section{Overview}

The last decade has witnessed many innovations of information technology (IT) that achieved strategic advantage for the innovating firm by changing the nature of competition in an industry. Much of this advantage occurred because IT significantly improved the good offered to the customer or reduced costs for the same good. Examples include American Hospital Supply Corporation's ASAP (HBS Case Services, 1985a), McKesson's Economost (Clemons and Row, 1988), and the topic of this study, Pacific Pride System's Cardlock IT (HBS Case Services, 1985b). These strategic IT initiatives are applications of an important principle from Industrial Organization, namely, the principle of material differentiation. This principle argues that unless there are structural differences between firms, firms would prefer to have goods that are as "different" as possible because they can soften price competition by serving different segments of the market. ${ }^{1}$ Our fundamental argument is that IT can add value for the customer and that this resulting quality differentiation can be used as a strategy to partition the market, thereby reducing the intensity of price competition between segments. ${ }^{2}$ Thus, this paper views the main role of IT as quality differentiation - in other words, adding value for the customer-and focuses on its resulting effect on prices. 3,4 This argument is consistent with Klein and Leffler (1981) who show under very general conditions that “...consumers can 
successfully use price as an indicator of quality' (p. 634).

The purpose of this paper is, first, to empirically establish that IT can indeed add value to a firm's production activities and, second, to quantify this value. To fulfill this purpose in a rigorous way, the paper takes advantage of the natural experimental controls occurring in the situation where price premiums have been charged for a homogeneous commodity delivered through IT, as compared to the same commodity not delivered through IT. Thus, the study presents results that show price premiums based on ITenabled characteristics that have been charged for an otherwise undifferentiated good. There has been much anecdotal evidence of price premiums through the use of IT, for example, American Hospital Supply Corporation's ASAP system (Harvard Case Services, 1985a) and Pacific Pride Systems (Harvard Case Services, 1985b). There are no empirical studies in major journals, however, that have shown the existence of these premiums over a period of time. While this paper studies the effect of IT on price, it does not address the issue of return on IT investment. The purpose of this paper is not to establish that the price premiums based on IT provide an abnormal return on investment because it is not relating the premiums to underlying costs. What the paper does provide is a step in this direction by focusing on the fact that added value to customers provided by IT can be reflected in market prices customers are willing to pay for an IT-enhanced good. Because the good studied is a homogeneous commodity, the IT impact on price can be isolated-the traded goods are indistinguishable, and, therefore, the different delivery method must account for the differences in price.

A classic example of a homogeneous commodity is fuel for vehicles. In spite of oil industry marketing, customers perceive little difference in fuel quality based on brand. Differentiation in the fueling industry is based on location and level of service, and in spite of this differentiation, fuel is highly price elastic (Slade, 1987). This study examines the application of IT to commercial fueling in the case of Pacific Pride Systems. Pacific Pride is a commercial vehicle fueling company that has used IT in the form of a "Cardlock" sys- tem to enhance service to its customers. The IT Cardlock improved the delivery of fuel through convenience (access to fuel at any time and in many locations), credit (favorable payment terms), and control (directing the location of the fuel purchase and providing detailed information about every fuel transaction).

In the context of Pacific Pride there are three possible explanations for a price premium: convenience, credit, and control. For the customer the value of convenience comes from unlimited access, which is IT-based, and location, which is not. Customer value from credit is based on how long a customer can delay making payment and on how easy it is to obtain credit, neither of which is IT-based. Finally, the value a customer receives from control relates to monitoring and constraining its fleet's activities, which is IT-based. Each of these possible explanations is addressed in our discussion.

In general, for industrial customers IT can add value to the traded good, lowering production costs. These costs can be reduced by IT through economies of scale and by productivity improvements (Barrett and Konsynski, 1982). 5 During the period when a supplier has an IT advantage over other suppliers and can thus lower customer costs, this advantage can be exploited by charging higher prices for goods sold through IT. These advantages are not sustainable but do exist, while the IT investment, expertise, and coordination costs act as a temporary barrier to other competitors' entry.

In addition to receiving added value from IT, customers typically incur IT adoption costs. Because IT adoption may be costly, some may not adopt. For the adopting customer there is a "one-shot" cost of integrating the new IT into normal operations (Bakos, 1991).6 Occasionally these costs involve terminating previous contractual arrangements (Chismar and Meier, 1992) and may include costs that result from organizational resistance and behavioral inertia (Van de Van, 1986), organizational learning (Ettlie, 1986) and justification of adoption (Tushman and Nelson, 1990). Implicit subsidies-for example, training or customer service-have been suggested to overcome these 
costs (Nault and Dexter, 1992), an issue that is addressed later. 7

The paper. proceeds as follows. The next section describes the research methods, analyzes the supplier, and discusses its pricing policy for Cardlock fuel. The succeeding sections outline our data collection procedures, examine the increased value customers receive from the Cardlock system, outline the costs of adopting the IT, and analyze Pacific Pride's Cardlock fuel pricing. The final section summarizes the conclusions and insights from the Pacific Pride pricing analysis.

\section{Research Method}

This section describes the environment studied and the nature of the IT used at our research site. This discussion is followed by an explanation of the data collection procedures.

\section{The research site and the IT}

The research site was Pacific Pride Systems in Salem, Oregon, which operates a commercial vehicle fueling system. The fueling system comprises a network of fuel stations covering most of the west coast of the United States, predominantly the Pacific Northwest. Customers are organizations that maintain a vehicle fleet, with sizes ranging from large trucking companies moving freight along the interstate highways to small local florists with one or two delivery vans. Pacific Pride maintains both retail and commercial Cardlock fueling stations, often on the same site, i.e., a fueling station with two islands: one retail and one Cardlock. More recently, the Pacific Pride network has included affiliates or franchises, a structure that has been modeled in Nault and Dexter (1994).

The commercial fueling stations are unattended, with operations similar to automated teller machines. A driver drives the vehicle into the fuel station, inserts a plastic punched card into a card reader, inputs an identification number and optionally the vehicle odometer reading, and is subsequently allowed access to the fuel pumps. The system then collects data on the amount of fuel purchased and records time/location of the fuel transaction. 8 We refer to these stations as Cardlock stations.

At the end of a billing period customers receive an itemized statement, which includes the card number, the personal identification number of the card user, the amount of fuel purchased, the time and location of the purchase, and optionally, the odometer reading at the time of the fuel purchase for each transaction. This information adds value by allowing customers to control their fuel costs by improved monitoring of the fuel transaction. Moreover, the fueling location decision is taken out of the hands of the vehicle driver: the driver is provided with a card to purchase fuel from a station on the Pacific Pride network; this card does not permit purchases elsewhere.

Through interviews with Pacific Pride's management, we found that they have a general policy model for setting fuel prices at the Cardlock facilities. In this policy model, retail competition determines the Cardlock prices, as the diagram below illustrates.

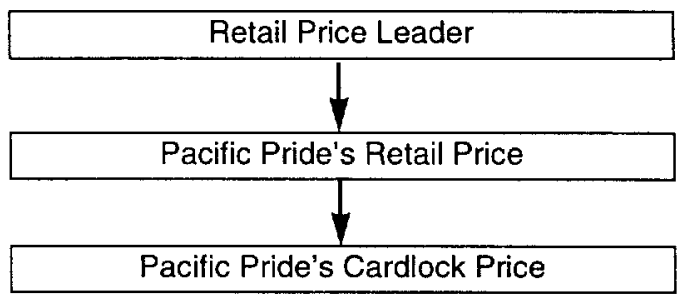

This model indicates that Pacific Pride bases its retail price on the retail price from the retail price leader and bases its Cardlock price on its retail price. In this way, Pacific Pride's retail and Cardlock prices react to competitive pricing. In the region examined in this study Pacific Pride tollows the retail price behavior of Atlantic Richfield Company (ARCO). Pacific Pride ties its retail prices closely to this local competition. These prices react quickly to changes in prices by the price leader, sometimes in a matter of hours, a structure that has been modeled as tacit collusion (Green and Porter, 1984). 
Pacific Pride's Cardlock pricing policy is to react to changes in the retail price by charging a premium per gallon competitive with credit card pricing. Pacific Pride sees the premium as directly attributable to the IT advantages the Cardlock system provides its customers. In other words, Pacific Pride ascribes the premium to the additional value IT gives its customers rather than a markup on costs to obtain an increased return on investment.

\section{Data collection}

The research method combines structured interviews and statistical analyses. The interviews focus on the impacts of IT discussed in the overview. In particular, we investigated the nature of added value to customers from IT and the impact of customer IT adoption costs. The statistical examination tested the relationship between fuel prices at retail fueling outlets and fuel prices at Pacific Pride's Cardlock stations. Specifically, we examined whether the premium pricing policy was supported empirically.

The structured interviews were conducted with two Pacific Pride senior executives. The composition of the questions for the interviews was derived from our hypotheses about the impacts of IT, making directed interviews possible. With permission of the participants, the interviews were audio taped, allowing transcripts from which in-depth data could be verified. Items pertaining to each aspect of the IT impacts were taken from the transcripts by each of us independently. The two sets of items were then compared. Areas of differences were resolved by re-examining the transcripts of the interviews.

For the statistical analysis, Pacific Pride provided time series of its own and its competitors' retail prices, and a time series of Cardlock prices. This data was available because Pacific Pride had retail and Cardlock fuel outlets. In addition, the executives obtained surveys of competitors' fuel prices. Bi-weekly data were available for the period January 1987 to June 1988 , or 36 observations. Per-gallon fuel prices were obtained for regular and no-lead gasoline at Pacific Pride's retail and Cardlock outlets as well as for the acknowledged retail price leader in the region, ARCO. The retail data were collected for two cities in OregonSalem and Eugene. These cities were considered to be in the same Cardlock pricing region. Thus, the same Cardlock fuel price series applied to both cities. The retail outlet data were taken from competitive fuel station pricing surveys conducted in each city. These surveys were conducted at least 3-4 times per month. Cardlock outlet prices were taken from computer reports produced at Pacific Pride, detailing Cardlock prices for each region in the network. Observations of the Cardlock fuel prices and retail fuel prices were not perfectly matched; the date of the retail fuel price surveys and the date on the computer-generated Cardlock fuel prices did not always correspond. The computer-generated Cardlock fuel price observations, however, included each price change made to the regional Cardlock prices; thus the Cardlock prices in the intervening periods were known. For retail fuel outlets, it was assumed that prices were stable throughout the periods between retail fuel price surveys. Although more than one price change might have been made at the retail fueling outlets between two price surveys, this outcome was unlikely. Typically, fuel prices are stable for long periods of time, as each of our eight time series of fuel prices demonstrated. While the results are specific to the commercial fueling industry, there was control for location (two cities), type of fuel (regular and no-lead), and type of outlet (Pacific Pride Cardlock, Pacific Pride retail, and ARCO retail). In effect, this controls for alternative explanations idiosyncratic to location, fuel, and outlet.

\section{Analysis of Increased Customer Value From IT}

IT is viewed as directly affecting the value customers obtain from increased quality. To capture this added value customers must adopt the new IT, and this adoption is typically costly. This section examines both the added value customers received from the Cardlock system and the customers' cost of IT adoption. 


\section{Added value from IT}

In an industrial market, the increased quality from IT translates into decreases in the customers' costs of production. In this case, the Cardlock system resulted in cost reductions for commercial fuel customers, exclusive of the price paid per gallon.

We argue that the use of IT has provided a unique service offering - IT differentiates Pacific Pride from the competition and as a result, Pacific Pride is able to obtain a price premium for fuel. The basis of this differentiation is the cost advantages provided to customers. Pacific Pride categorized the customers' cost advantages as the three "Cs": convenience, credit, and control, which are listed in Table 1 and are discussed below in turn. Essentially, these are the reasons why customers are willing to pay a premium per gallon for fuel through the Cardlock.

The convenience customers obtained through IT is explained as follows. Through the use of IT, Pacific Pride provided an electronically linked network of unattended fuel stations. This network was unique in the combination of locations and the electronic links across the network. Customers had convenient access to this network of fueling stations, 24 hours a day, seven days a week, with no holiday closures. Through the electronic links, customers received a single, bi-weekly itemized statement for fuel purchases throughout the network, which saved on transaction and monitoring costs. In addition, more timely information could be made available to the customers on request. There were other convenience characteristics as well. Drivers were not required to carry cash or other credit cards. Typically, drivers took less time to refuel because lineups at retail stations were avoided

Table 1. Added Value From IT

1. Convenience: multiple locations, 24 hours/day, 7 days/week

2. Credit: terms equivalent to general purpose credit cards

3. Control: complete monitoring of the fuel purchase (i.e., the general public did not have access to the Cardlock stations). As a substitute, some larger customers had the option of maintaining their own fuel depots. However, the underground storage tanks needed for this type of operation required constant monitoring for leaks and were subject to extensive government regulation, both of which incurred significant overhead. Furthermore, there was still the potential problem of requiring multiple fueling locations.

Credit was the second area where customers reduced costs. Compared to cash or electronic funds transfers, the bi-weekly billing from the Cardlock system extended credit to customers. General-use (e.g., Visa) or fuel-specific (e.g., Shell) credit cards also had this feature, although these cards may have had additional charges. We argue that the credit advantages of Pacific Pride's Cardlock are not its differentiating feature, i.e., there is little credit difference between Cardlock and other credit cards. However, Pacific Pride needed to offer credit that was comparable to competing cards.

Superior control played an essential role in customer cost savings from use of the IT Cardlock. Essentially, the Cardlock system removed the fueling decision from the customers' drivers, thereby reducing the potential for opportunistic behavior on the part of drivers who might purchase items other than fuel with the card. If drivers were given cash or credit cards for fuel, they and/or fuel station attendants could divert, for personal gain, some of the funds recorded as fuel purchases. Cash in the hands of a driver is most easily diverted for personal use. Credit cards only partially eliminate these problems. During our interviews, a Pacific Pride executive explained that non-fuel purchases can easily be recorded as fuel. A related problem is that credit cards can be charged for amounts greater than the fuel purchase, with the difference ending up as cash in the driver's and/or service station attendant's pocket. Quoting from a truckstop owner, "One issue, no matter whose credit card we talk about, is that trucking companies don't want to use cards at all because drivers have 500 miles to think about ways to screw you" (Harvard Case Senvices, 1988). 
Thus, the Cardlock system offered greater control than credit cards because (1) the card could only be used for fuel purchases, and (2) a transaction could not be recorded for an amount larger than the actual fuel purchase. Moreover, the activity control from the itemized statements gave a time-and-location stamp for each transaction, providing further ability to track and monitor drivers. Therefore, the Cardlock reduced the opportunities for embezzlement and provided some degree of monitoring. The full-reporting feature was also used by some customers to schedule maintenance on their vehicle fleet. The problem of pilferage from a customer's proprietary underground storage tanks was also eliminated by adopting the Cardlock system; the Cardlock records every gallon of fuel taken from inventory. Clearly, the control offered by the Cardlock system is feasible only through the use of IT.

\section{IT adoption costs}

Adoption of new IT entails costs on the part of the customer. Pacific Pride's management believed customer adoption costs were low, but not necessarily zero. There was a cost of training drivers to use the Cardlock equipment, which was considered a larger problem if the driver had limited literacy skills. There was an additional cost of issuing and distributing cards to the drivers, usually borne by the customer's dispatcher. Thus, the dispatcher was critical in ensuring a smooth transition to the Cardlock system. Customers were also forced to sell the concept to their drivers. Common objections from drivers were that they benefitted from truck stops that had food and shower facilities, objections that suggested extra costs from driver resistance: drivers disliked the rigid controls and missed the social aspects of regular truck stops. One of the key education/training costs was the time drivers took to locate all the Cardlock fueling stations. Finally, there were immediate internal costs of adjusting to new reports, statements, etc., although these costs decreased after an adjustment period.

For the period under study, Pacific Pride did not impose a fixed fee for adoption. Initially, cus- tomers were required to pay a $\$ 25-\$ 50$ deposit, ostensibly to cover minor card imprinting costs, which could be waived if the customer objected. Pacific Pride's marketing efforts to gain customer adoption through an adoption subsidy were also examined. If convinced it would be successful, the executives indicated they would use a subsidy. Management estimated a cost upper limit of $\$ 500$ to add a customer to the system, mostly made up of sales effort, incentives, and general telemarketing schemes. Although the need for a minimum volume requirement for subsidized customers was recognized, if they were able to add customers to the system, then management suggested they would pay up to this limit as a subsidy.

An implicit subsidy was already in use. Customers received help from Pacific Pride in the form of explanations and meetings with the customer's staff to ease the transition from previous methods of purchasing fuel to the Cardlock system, as well as to keep the customers up to date with the network. Generally, these actions suggest resources in the form of effort being directed toward overcoming the customer's switching costs. Pacific Pride's senior management clearly recognized they were providing these implicit subsidies.

\section{Pricing Evidence}

The evidence of Pacific Pride's premium pricing is presented by describing the evolution of the Cardlock price from a discount in early years to a price premium. The empirical results and statistical tests are then presented.

\section{History}

Pacific Pride has not always followed a policy of premium pricing at Cardlock stations. Studying the evolution of their pricing policy indicates the change in reasoning that is behind premium pricing at the Cardlock. Prior to 1983, the price at the Cardlock was lower than retail. This discount was defended by management who rea- 
soned that the Cardlock was self serve, often had no canopy to protect against the weather, and therefore provided less than a full-service station. In addition, between 1979 and 1983 the Cardlock system had implementation and operational difficulties. In 1983, however, one of Pacific Pride's executives visited a similar facility in San Diego that was charging a premium per gallon. The manager of the San Diego company justified the price premium by arguing that the commercial fuel supplier was providing convenience, carrying credit, as well as providing superior control through the Cardlock system. When informed that Pacific Pride was selling fuel through the Cardlock at a discount, the San Diego executive stated: "...you are leaving money on the table."

Upon returning to Salem, the Pacific Pride executive acknowledged that a discount was an erroneous strategy because Cardlock was in fact providing superior service and immediately ordered an increase in the price at Cardlock so that Cardlock fuel was priced at a premium. Sales personnel forecasted a loss of customers, and one salesman resigned. The resulting effect on the customer base, however, was minor and perhaps even beneficial: only a few smaller-volume customers were lost. Because of Pacific Pride's fixed costs of maintaining a customer's account, it actually benefitted when a few less desirable customersthose with low volume that provided little if any profit-left the system. These smaller customers were likely shopping for fuel based only on price, and thus they did not receive sufficient value from the IT to justify paying the premium for Cardlock fuel. There was little change for larger commercial customers because the IT benefits to customers, in particular the additional convenience and control, increased more than proportionally with customer size. Thus, rather than each individual customer purchasing less, demand was affected only by smaller customers leaving the system.

During the period under analysis, competition offering similar services to Pacific Pride's Cardlock network was fragmented. Pacific Pride identified three other commercial networks covering parts of the west coast: NCN, CFN, and Gas Card. NCN used the same equipment as Pacific Pride, but it primarily targeted interstate truckers. Most NCN stations were diesel only, competed on the basis of price, and typically used Chevron distributors. In contrast, 40-45 percent of Pacific Pride fuel volume was gasoline rather than diesel. CFN also linked to Chevron stations, had been a late starter. Finally, Gas Card was reorganized after filing for bankruptcy and then had ties to ARCO. Gas Card had many nodes but few customers. Pacific Pride's management believed any competitor linked to a major oil company was disadvantaged because the majors were slow to move with implementations of IT. Moreover, most major's sites were independently owned. Compared to Pacific Pride, these competitors spent less on advertising and customer recruitment. Still another layer of competition comprised small, local operators covering a city or county. These small, local networks were effective in capturing local business, but they were handicapped when customers had operations outside the local network's scope.

It is clear that none of Pacific Pride's commercial fueling competitors, local or national, offered the equivalent or better package of services. The combination of convenience and control was the unique advantage of the Cardlock system. The competitors that managed to implement IT were limited in type of fuel or had a restricted network, which meant customers were less likely to be able to fuel their fleets on a single network. As a result, for a limited time, Pacific Pride could have been considered a monopoly in its Cardlock system offering, at least with respect to its targeted customer base. This monopoly could be characterized by what the system offered and by the locations spanned (i.e., a series of local monopolies), consistent with the theme of ITbased differentiation.

As a final point, it is well known that demand for fuel is highly price elastic. This price elasticity persists even if the fuel offerings are differentiated (for example, see Slade, 1987). 


\section{Results}

\section{Determination of Cardlock Prices: The Policy Model}

Pacific Pride's management stated that its Cardlock pricing policy was based on its retail prices, which were triggered by the reputed price leader, ARCO. The first step is retail competition; that is,

Retail Price Leader $\rightarrow$ Pacific Pride's Retail Price

Retail fuel prices between suppliers were highly correlated. Consistent with this observation, in multiple locations correlations of .9 and higher were found between the ARCO retail price and the Pacific Pride retail price. These correlations were significant at all levels, and are given in Table 2.

The second step is retail to Cardlock:

\begin{tabular}{|c|}
\hline $\begin{array}{c}\text { Pacific Pride's } \\
\text { Retail Price }\end{array} \rightarrow \begin{array}{l}\text { Pacific Pride's } \\
\text { Cardlock Price }\end{array}$ \\
\hline
\end{tabular}

Table 3 gives the correlations between Pacific Pride's retail and Cardlock prices by city. The correlations were significant at all levels. Figures 1 through 4 show graphs of regular and no-lead fuel in each city. These results confirm a strong, positive relationship between retail fuel prices and Cardlock fuel prices.

Table 2. Correlations Between ARCO Retail and Pacific Pride Retail Prices

\begin{tabular}{|l|c|c|c|c|}
\hline \multirow{2}{*}{} & \multicolumn{2}{|c|}{ PP Retail Regular } & \multicolumn{2}{c|}{ PP Retail No-Lead } \\
\cline { 2 - 5 } & Salem & Eugene & Salem & Eugene \\
\hline ARCO Retail Regular & .97 & .91 & & \\
\hline ARCO Retail No-Lead & & & .98 & .90 \\
\hline
\end{tabular}

Table 3. Correlations Between Pacific Pride Retail and Cardlock Prices

\begin{tabular}{|l|c|c|c|c|}
\hline \multirow{2}{*}{} & \multicolumn{2}{|c|}{ PP Cardlock Regular } & \multicolumn{2}{c|}{ PP Cardlock No-Lead } \\
\cline { 2 - 5 } & Salem & Eugene & Salem & Eugene \\
\hline PP Retail Regular & .97 & .89 & & \\
\hline PP Retail No-Lead & & & .96 & .90 \\
\hline
\end{tabular}

Table 4. Differences Between Pacific Pride Cardlock and Retail Prices

\begin{tabular}{|l|cccc|}
\hline Retail & $\begin{array}{c}\text { Mean } \\
\text { Difference }\end{array}$ & $\begin{array}{c}\text { Std Deviation } \\
\text { of Difference }\end{array}$ & $\begin{array}{c}\text { Lower 99\% } \\
\text { Conf. Interval }\end{array}$ & $\begin{array}{c}\text { Upper 99\% } \\
\text { Conf. Interval }\end{array}$ \\
\hline Salem PP Regular & .06972 & .00220 & .06373 & .07571 \\
\hline Salem PP No-Lead & .08028 & .00294 & .07227 & .08829 \\
\hline Eugene PP Regular & .04583 & .00344 & .03646 & .05520 \\
\hline Eugene PP No-Lead & .04361 & .00317 & .03497 & .05225 \\
\hline Salem ARCO Regular & .09778 & .00304 & .08950 & .10606 \\
\hline Salem ARCO No-Lead & .10833 & .00346 & .09890 & .11776 \\
\hline Eugene ARCO Regular & .09694 & .00342 & .08762 & .10626 \\
\hline Eugene ARCO No-Lead & .08556 & .00330 & .07657 & .09455 \\
\hline
\end{tabular}


January 1987 to June 1988, Biweekly

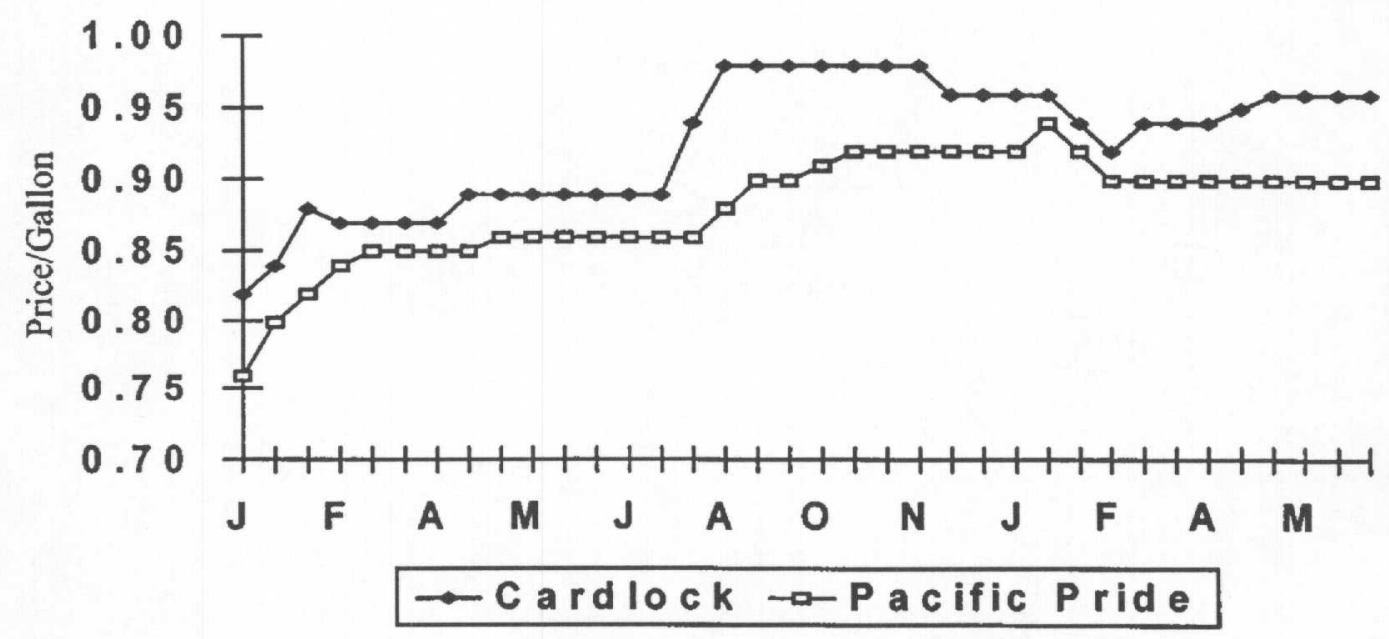

Figure 1. Fuel Prices: Eugene

(Cardlock vs. Pacific Pride: Regular Fuel)

January 1987 to June 1988 , Biweekly

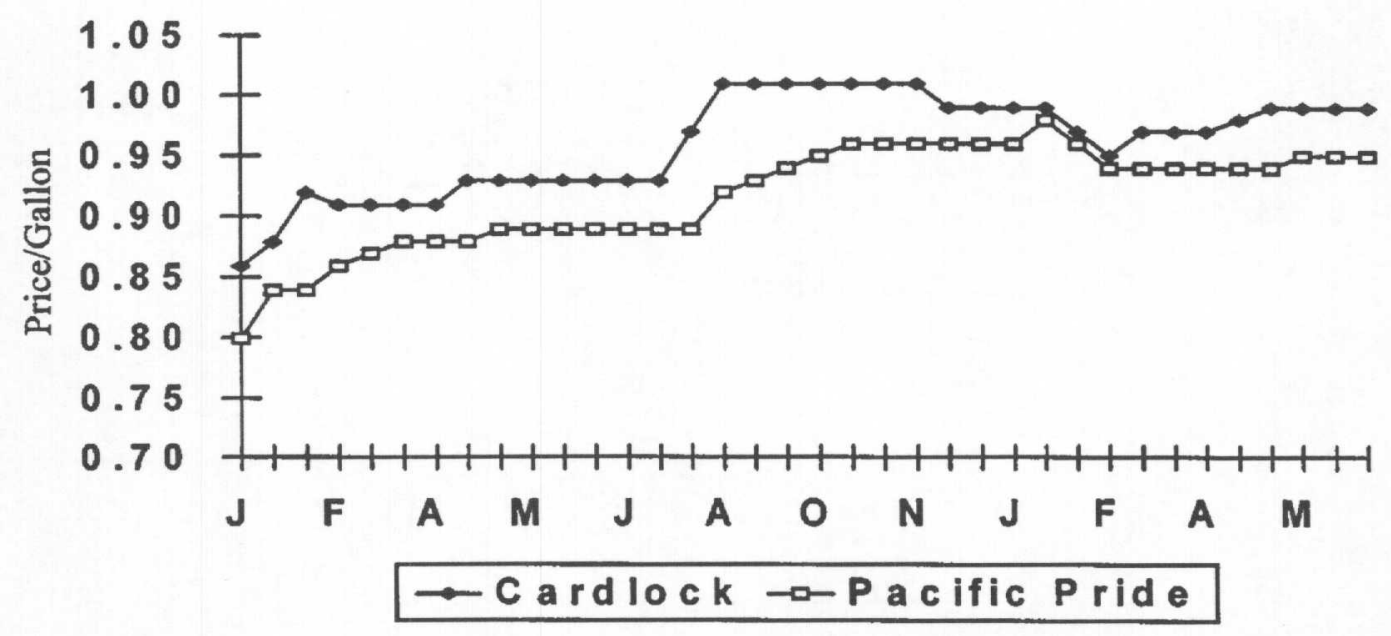

Figure 2. Fuel Prices: Eugene

(Cardlock vs. Pacific Pride: No-lead Fuel) 


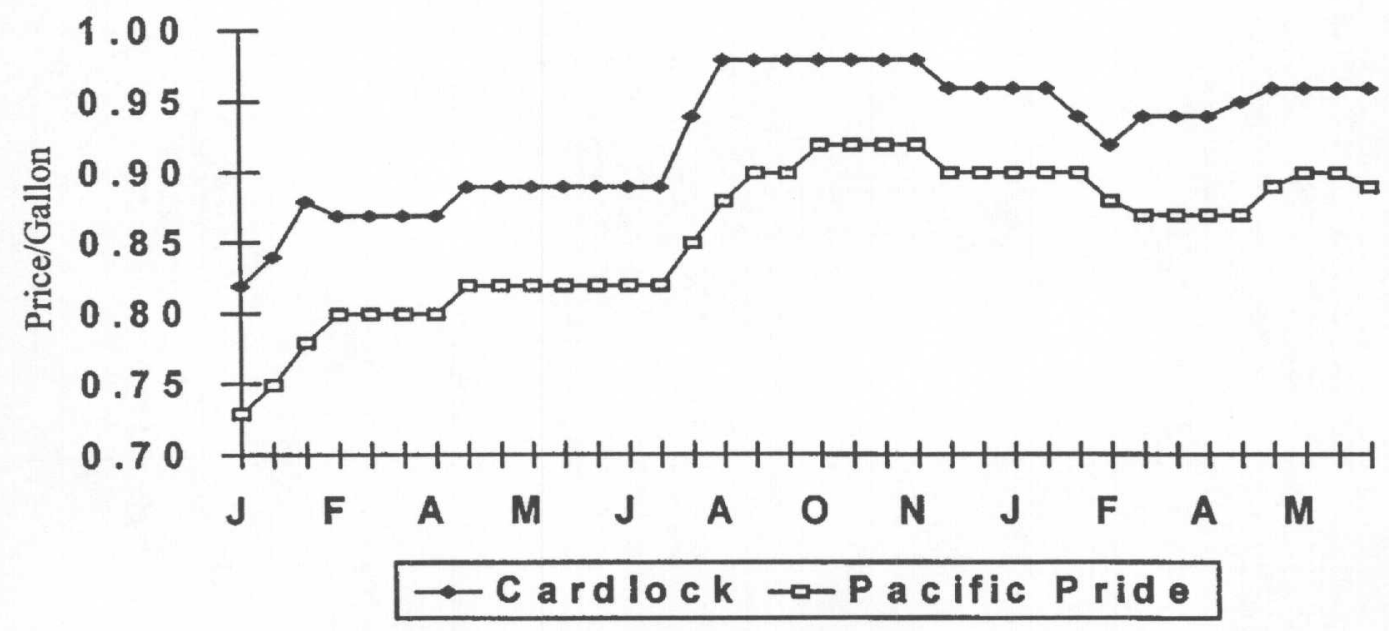

Figure 3. Fuel Prices: Salem

(Cardlock vs. Pacific Pride: Regular Fuel)

January 1987 to June 1988, Biweekly

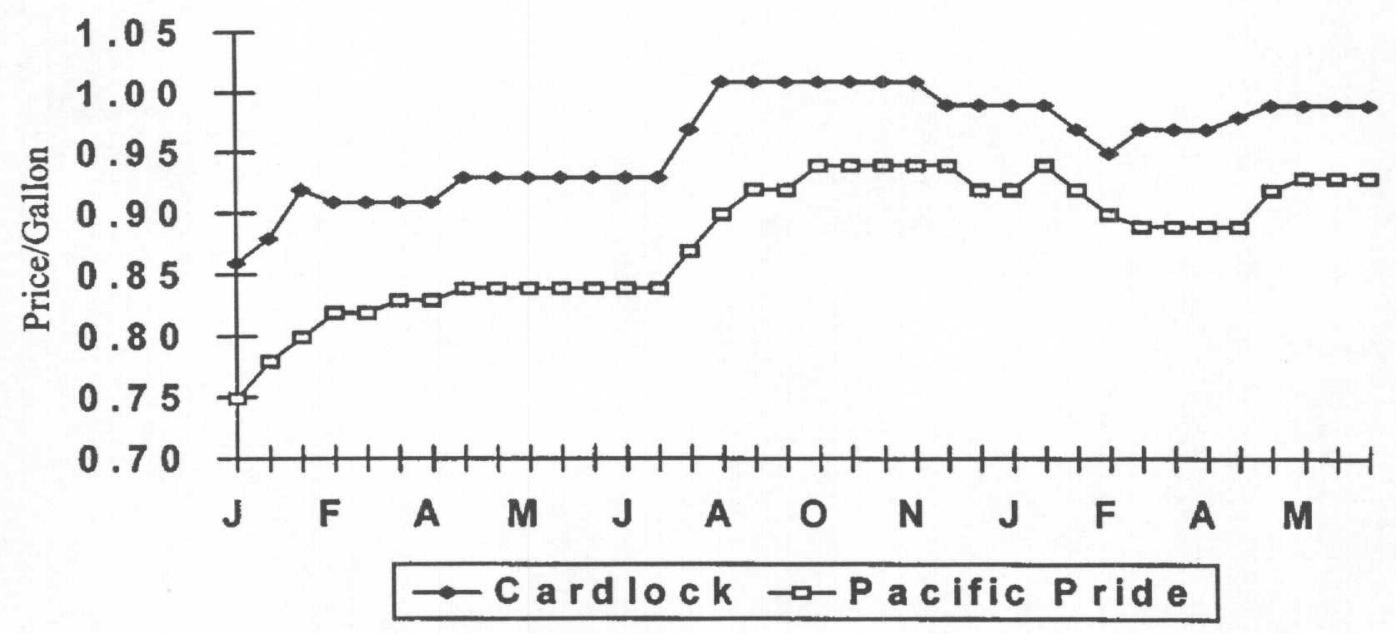

Figure 4. Fuel Prices: Salem

(Cardlock vs. Pacific Pride: No-lead Fuel) 


\section{Pricing Behavior}

In the framework of Pacific Pride's policy model, these results imply that retail fuel prices were the primary determinant of the prices charged at the Cardlock sites. The pricing rule was declared by Pacific Pride's executives as a fixed premium per gallon for fuel at the Cardlock site over the retail per gallon price. Results are presented for a fixed premium rather than a premium as a percentage of retail because the former was the specific policy model under study. Our examination of the latter did not yield further insight. Thus, the premium is a fixed markup on the retail price. To measure this pricing rule, we calculated estimates of the mean difference between the observed retail and Cardlock per gallon fuel prices.

The overall mean price premium was $\$ .0785$ per gallon. Table 4 provides the means and standard deviations of the estimates by location, retailer, and type of fuel, as well as lower and upper limits of a 99-percent confidence interval. Cardlock regular was matched with retail regular and Cardlock no-lead was matched with retail no-lead. The critical hypothesis for this analysis is whether Cardlock fuel was priced at a premium over retail. The null hypothesis is that there was no fuel price premium at the Cardlock outlets. For each of the eight cases in Table 4, it is easily verified that the null hypothesis is rejected at all reasonable levels of significance. Consequently, a premium per gallon was being charged at the Cardlock stations across locations, across retailers, and across types of fuel.

This result upholds our general hypothesis that the commodity (fuel) differentiated by IT (Cardlock system) provides cost savings to customers (those with vehicle fleets). Commercial customers are willing to pay more for fuel, with full knowledge of the alternatives, and thus the Cardlock system provides them with additional value. In this case, the value of the cost savings to customers was at least the per-gallon premium price of fuel paid at the Cardlock stations versus the normal retail outlets. Even using the lowest lower limit from a 99 percent confidence interval showed a $\$ .035$ per gallon price premium at the Cardlock. The market price of the added value from IT is between 4.8 percent and 12.3 percent of a customer's retail fueling cost. ${ }^{9}$ Restating, the customers place the minimum average value of the additional features that IT provides at between five and 12 percent of the underlying commodity.

This result is also insensitive to volume discounts. Pacific Pride's management indicated a system-wide discount of between $\$ .015$ and $\$ .0175$ per gallon based on its volume discount policy. Factoring the higher of these amounts into our statistical tests does not change any of the results. The smallest mean premium was $\$ .0436$ per gallon and, as discussed above, the lower 99 percent confidence limit was $\$ .035$ per gallon, almost twice the higher discount amount. Our discussions with Pacific Pride also revealed that competitors, both commercial and retail through fleet cards, used even higher volume discounts and targeted similar customers. The industry was described as having a volume, rather than a gross profit, focus so that volume discounts were ubiquitous. In other words, Pacific Pride's volume discount policy was based on matching the competition. Thus, our estimates of the price premiums should not be biased due to these discounts.

The relatively simple statistics we employed are sufficient to test our hypotheses. Regression analysis would reproduce the results with the overhead of additional assumptions (mostly related to residuals) and would provide estimates of slope and intercept, neither of which are interpretable in the context of the hypotheses.

\section{Rival Explanations}

Because our focus is on the effects of IT, rival explanations are possible explanations for a price premium that is independent of the IT. The naturally occurring controls-fuel as a homogeneous commodity-allow us to concentrate on rival explanations involving convenience, credit, and control. As stated in the introduction, part of convenience is due to location, which is not IT-based. Location was not a differentiating feature because almost all Pacific 
Pride stations had competition "across the cloverleaf "in retail areas and nearby in most commercial areas. Thus, most stations had a competitor within eyesight. As a result, location cannot be an explanation for the price premium. Customer value from credit is based on how easy it is to obtain credit and on how long a customer can delay making payment, neither of which is IT-based. Pacific Pride had bad debt losses similar to most major credit cards-onequarter to one-half percent. In fact, Pacific Pride believes they have stricter credit controls than their competitors. Pacific Pride bills their customers every two weeks rather than monthly, and thus, they offer less credit than their competition. Therefore, Pacific Pride did not offer any advantages in credit over their competitors, so credit cannot be an explanation for the price premium. Finally, the convenience of unlimited access is due to the automated stations, which is IT-based, and the value a customer receives from control relates to monitoring and constraining its fleet's activities, which is also IT-based. Unlimited access to stations was offered in various different forms by competitors; thus, this is unlikely to be an explanation for the price premium. However, competitors did not offer similar control features, and, as a result, we believe the control features to be the main explanation of why customers were willing to pay the price premium for fuel from Pacific Pride.

\section{Conclusions and Insights}

\section{Conclusions}

This paper has presented the economic rationale and empirical evidence for adding value for customers to a good based on IT. In the Pacific Pride case, strong support for IT increasing the quality of a homogeneous commodity has been shown. The increase in quality from convenience, credit, and control provided by the Cardlock system decreased internal costs of the customer. For the time period studied, powerful pricing results confirm that a significant price premium on the IT-enhanced commodity existed. The added quality from IT differentiated Pacific Pride, which mitigated direct competition in commercial fueling. As a result, Pacific Pride was able to charge a premium of five to 12 percent of the retail price per gallon on fuel. The fact that Pacific Pride was able to sustain a price premium measures customer behavior directly. There were no other changes in fuel or the delivery of fuel. Thus, for a typical Cardlock station selling an average of 60,000 gallons of fuel per month, using our overall average premium of $\$ .0785$, this premium translates into $\$ 4,710$ per month per station of additional revenue. ${ }^{10}$ These results are considerable testimony to the proposition of using IT to add value for the customer. As discussed, most of this added value is due to the convenience and control the IT affords the customer-that is, convenient access to fuel and control of the fuel purchase are the most important aspects of Cardlock for customers.

The presence of customer IT adoption costs is also supported in this case. Customers have small, but positive, Cardlock adoption costs. Customers have not explicitly been charged for IT adoption and Pacific Pride has considered subsidies to entice customers to adopt. Implicit subsidies in the form of direct customer support, however, are employed.

In spite of the above pricing results, there are limitations to our analysis. We have not examined the return on investment from the Cardlock system, nor can we comment on optimal supplier behavior. A more complete analysis would integrate the findings from the customer's viewpoint with a normative model of supplier decision making.

\section{Insights}

An important implication from this analysis is the long-standing issue of information system value. Quality enhancement with IT results in premium pricing that results from the added value IT provides to customers. In this case, the market determines the value of IT, directly assessing IT benefits to customers. If application of IT results in a price premium on the good over its price without IT, as it has in the Pacific Pride case, 
then part of the value derived from the IT is embodied in that premium. Thus, the value captured by the price premium is directly measurable, and it is an important step toward the evaluation of benefits from investments in IT. In this study, the effects of competition are embedded in the market mechanism and in the nature of the industry, effects that have been difficult to handle in larger studies of IT investment.

Answering the question, "when will IT result in higher prices?" requires information about customers' cost structure. For managers, this implies determining what value IT can add to help trade off against existing customers' costs. Added value typically means added service. In our example, even differentiated fuel offerings are price elastic. We speculate, however, that this differentiation is more a matter of perception (marketing) than reality. For Pacific Pride the differentiation is more substantial in that the Cardlock features allowed customers to reduce their internal control costs by at least as much as the fuel premium. Thus, we believe that ITbased differentiation will be priced when the IT features actually reduce customer costs.

A likely question is, "Why don't customers do this on their own?" In this case IT has allowed Pacific Pride to integrate information across locations, providing service that customers could not individually provide, at a reasonable cost, for themselves. As a result, customers effectively outsource some of their internal control requirements to Pacific Pride because Pacific Pride has an economies of scale advantage in two dimensions (locations and customers) for providing these services. It would seem that there remain many opportunities for using IT to capitalize on similar two or more dimension-scale advantages.

Managing control requirements through IT can take two forms: monitoring and incentives. In many instances, monitoring and incentives are substitutes (Milgrom and Roberts, 1992). In this case, the IT is used to monitor and incent by the full reporting features and the restrictions on where fuel can be purchased. Basing interoutlet agreements on the detailed information provided by systems like Pacific Pride's can allow for different divisions of profits. These dif- ferent divisions of profits can more fully reward those responsible for the profits. This can increase investment in areas like customer recruitment, thereby increasing profits in the network as a whole (Nault, forthcoming; Nault and Dexter, 1994).

\section{Acknowledgements}

Partial support was provided by the Society for Information Management and by the Social Sciences and Humanities Research Council of Canada. The authors are grateful for the cooperation of Cynthia Condon and Mike Truax from Pacific Pride Systems. We also thank the editor, associate editor, and anonymous reviewers for their helpful comments.

\section{Endnotes}

${ }^{1}$ For example, Mussa and Rosen (1978), Gal-Or (1983), and Shaked and Sutton (1982). This principle is also consistent with a niche strategy (Porter, 1980).

${ }^{2}$ From a Schumpeterian viewpoint, competition through innovation is analogous to gaining from differentiationhere, using IT as the differentiating innovation.

${ }^{3}$ For further discussion, see Clemons and Row (1991); for an IT model based on quality differentiation, see Barua, et al. (1991); and for a cooperative model, see Clemons and Kleindorfer (1992).

${ }^{4}$ This added value corresponds with the traditional micro economic theory of the consumer, as outlined in Hitt and Brynjoltsson (1994).

${ }^{5}$ Further evidence for customer cost reductions is provided in Parsons (1983), Porter and Millar (1985), and Cash and Konsynski (1985)

6 For an IT model, see Davamanirajan, et al. (1991).

${ }^{7}$ Although not the focus of this paper, the supplier also benefits from IT through economies of scale and productivity improvements. In particular, the supplier's cost structure shifts to one with lower variable costs. These lower variable costs are offset by increased fixed IT costs. Fixed implementation and operating costs are typically the largest IT costs, counterbalancing the variable cost reductions. The remaining $I T$ costs are costs of adding new customers onto the system and marginal costs per transaction. This latter cost is often negligible (Kauffman, 1988; Bakos, 1991). Thus, the marginal costs of production with IT fall below those without IT. Additional evidence can be found in Copeland and McKenney (1988) and Clemons and Row (1988). This says nothing about total costs. The 
costs of increased risk, for example, are unlikely to affect marginal costs, but they will affect total costs.

8 More information on the technical aspects of the system can be found in HBS Case Services (1985b, 1985c, 1988) or can be obtained from the authors.

${ }^{9}$ These figures were obtained by dividing the per-gallon premium by the appropriate retail per-gallon price, taking the upper and lower limits of the numbers generated.

10 The figure of 60,000 per month is taken from Pacific Pride Commercial Fueling Systems (B) (Harvard Case Services, 1985c).

\section{References}

Bakos, J.Y. "A Strategic Analysis of Electronic Marketplaces," MIS Quarterly (15:3), September 1991, pp. 295-310.

Barrett, S. and Konsynski, B.R. "InterOrganization Information Sharing Systems," MIS Quarterly, Special Issue, 1982, pp. 93-105.

Barua, A., Kriebel, C.H., and Mukhopadhyay, T.H. "An Economic Analysis of Strategic Information Technology Investments," MIS Quarterly (15:3), September 1991, pp. 313-331.

Cash, J.I. and Konsynski, B.R. "IS Redraws Competitive Boundaries," Harvard Business Review (63:2) March-April 1985, pp. 134-142.

Chismar, W.G. and Meier, J. "A Model of Competing Interorganizational Systems and its Application to Airline Reservation Systems," Decision Support Systems (8:5), September 1992, pp. 447-458.

Clemons, E.K. and Kleindorfer, P. "An Economic Analysis of Interorganizational Information Systems," Decision Support Systems (8:5), September 1992, pp. 431-446.

Clemons, E.K. and Row, M. "McKesson Drug Company: A Case Study of Economost-A Strategic Information System," Journal of Management Information Systems (5:1), Summer 1988, pp. 36-50.

Clemons, E.K. and Row, M. "Sustaining IT Advantage: The Role of Structural Differences," MIS Quarterly (15:3), September 1991, pp. 275-292.

Copeland, D.G. and McKenney, J.L. "Airline Reservation Systems: Lessons From
History," MIS Quarterly (12:3), September 1988, pp. 353-370.

Davamanirajan, P. Kriebel, C.H., and Mukhopadhyay, T.H. "Information Technology Innovation and Competition in the Presence of Switching Costs," Proceedings of the Twelfth International Conference on Information Systems, J.I. De Gross, I. Benbasat, G. DeSanctis and C. Beath (eds.), New York, NY, December 16-18, 1991, pp. 1-14.

Ettlie, J. "Implementing Manufacturing Technologies: Lessons from Experience," in Managing Technological Innovation, D.D. Davis and Associates (eds.), Jossey-Bass Publishers, San Francisco, CA, 1986, pp. 72-104.

Gal-Or, E. "Quality and Quantity Competition," Bell Journal of Economics (14:2), Autumn 1983, pp. 590-600.

Green, E.J. and Porter, R.H. "Noncooperative Collusion Under Imperfect Price Information," Econometrica (52:1), January 1984, pp. 87-100.

HBS Case Services. "American Hospital Supply Corp. (A) The ASAP System," 9-186-005, Harvard Business School, Boston, MA, 1985a.

HBS Case Services. "Pacific Pride Commercial Fueling System (A)," 9-186-014, Harvard Business School, Boston, MA, 1985b.

HBS Case Services. "Pacific Pride Commercial Fueling System (B)," 9-186-015, Harvard Business School, Boston, MA, 1985c.

HBS Case Services. "Pacific Pride Commercial Fueling System (C)," 9-188-084, Harvard Business School, Boston, MA, 1988.

Hitt, L. and Brynjolfsson, E. "The Three Faces of IT Value: Theory and Evidence," in Proceedings of the Fifteenth International Conference on Information Systems, J.I. DeGross, S.L. Huff, and M.C. Munro (eds.), Vancouver, B. C., December 14-17, 1994, pp. 263-277.

Kauffman, R.J. Assessing the Performance of Information Technology Which Deliver Financial Services, unpublished Ph.D. thesis, Carnegie-Melon University, Pittsburgh, PA, 1988.

Klein, B. and Leffler, K.B. "The Role of Market Forces in Assuring Contractual 
Performance," Journal of Political Economy (89:4), 1981, pp. 615-641.

Milgrom, P. and Roberts, J. Economics, Organization and Management, Prentice Hall, Englewood Cliffs, NJ, 1992.

Mussa, M. and Rosen, S. "Monopoly and Product Quality," Journal of Economic Theory (18:2), August 1978, pp. 301-317.

Nault, B.R. "Mitigating Underinvestment Through an IT-Enabled Organization Form," Organization Science, 1996 (forthcoming).

Nault, B.R. and Dexter, A.S. "Interorganizational Information Systems in Industrial Markets," Chapter 14 in Strategic Information Technology Management: Perspectives on Organizational Growth and Competitive Advantage, R. Banker, R.J. Kauffman, and M. Mahmood (eds.), Idea Group Publishing, Harrisburg, PA, 1992, pp. 297-316.

Nault, B.R. and Dexter, A.S. "Adoption, Transfers and Incentives in a Franchise Network with Positive Externalities," Marketing Science (13:4), Fall 1994, pp. 412-423.

Parsons, G.L. "Information Technology: A New Competitive Weapon," Sloan Management Review (25:1), Fall 1983, pp. 3-14.

Porter, M.E. Competitive Strategy, Free Press, New York, NY, 1980.

Porter, M.E., and Millar, V.E. "How Information Gives You Competitive Advantage," Harvard Business Review (63:4), July-August 1985, pp. 149-160.

Shaked, A. and Sutton, J. "Relaxing Price Competition Through Product Differentiation," Review of Economic Studies (49), 1982, pp. 3-13.

Slade, M.E. "Interfirm Rivalry in a Repeated Game: An Empirical Test of Tacit Collusion," Journal of Industrial Economics (35:4) June 1987, pp. 499-516.
Tushman, M.L. and Nelson, R.R. "Introduction: Technology, Organizations, and Innovation," Administrative Science Quarterly (35:1), March 1990, pp. 1-8.

Van de Ven, A.H. "Central Problems in the Management of Innovation," Management Science (32:5), May 1986, pp. 590-607.

\section{About the Authors}

Barrie R. Nault is assistant professor in the Graduate School of Management, University of California, Irvine. His research interests include the economic impacts of interorganizational information systems, the design of incentives in networks, centralization/decentralization of organizations, and the timing of technology introduction. He has articles published or forthcoming in journals such as Information Systems Research, Journal of Money, Credit and Banking, Management Science, Marketing Science, and Organization Science. He serves as associate editor for Information Systems Research.

Albert S. Dexter is professor in the Faculty of Commerce and Business Administration, University of British Columbia. His research interests include the relationship between information technology and competitive advantage, and electronic data interchange. He has served as an expert witness for the Supreme Court of British Columbia on issues of economics and software copyright infringement. He has published in journals such as The Accounting Review, Communications of the ACM, INFOR, Journal of Accounting Research, Journal of Money, Credit and Banking, MIS Quarterly, Management Science, and Marketing Science. He serves as associate editor for INFOR. 


\section{Appendix}

Letting $X t$ represent the retail price per gallon at time $t$, and $y t$ represent the Cardlock price per gallon time $t$, the pricing rule was

$$
y t=x t+\Delta
$$

where $\Delta$ is a constant. To measure this pricing rule, the expression can be written as

$$
y t-x t=\Delta+\varepsilon t
$$

where $\varepsilon t$ captures the deviations from the pricing rule. Thus, $\bar{\Delta}$ is the estimate of the mean differenc between the observed retail and Cardlock per gallon fuel prices. An unbiased estimator of $y_{t}-x_{t}$ $\bar{\Delta}=\sum_{i=1}^{n} \frac{\left(y_{t}-x t\right)}{n}$, assuming $E(\varepsilon t)=0$ where $E$ is the expectation operator. An unbiased estimate $\operatorname{Var}\left(y_{t}-x_{t}\right)$ is $\operatorname{Var}(\varepsilon t)=\sum_{i=1}^{n} \frac{\left(y_{t}-x t-\bar{\Delta}\right)^{2}}{n-1}$. With a sample size of $n=36$, the Central Limit Theore gives a sampling distribution for $\bar{\Delta}$, which is approximately Normal with mean $\bar{\Delta}$ and varianc $\operatorname{Var}(\bar{\Delta})=\frac{\hat{\operatorname{Var}(\varepsilon t)}}{n}$.

The hypothesis is whether Cardlock fuel was priced at a premium over retail,

$$
\begin{aligned}
& \text { Ho: } \Delta \leq 0 \\
& \text { Ha: } \Delta>0
\end{aligned}
$$

where the null hypothesis is that there was no fuel price premium at the Cardlock outlets. For each of tr eight cases in Table 4, the null hypothesis is rejected at all reasonable levels of significance. 